\title{
JUDGING THE OTHER: THE INTERSECTION OF RACE, GENDER, AND CLASS IN FAMILY COURT
}

\author{
Vicki Lens
}

This critical ethnographic study of family court child maltreatment proceedings describes and illuminates the ways in which racial, gender, and class disadvantages can manifest on the ground as judges, attorneys, social service workers, and parents - joined often by gender but split by race and class-adjudicate cases. The findings suggest that intersectionality worked in ways that exponentially marginalized poor mothers of color in the courtroom. They were marginalized both through the rules of the adversarial process (which silenced their voices) and through the construction of narratives (which emphasized individual weakness) over structural obstacles as well as personal irresponsibility over expressions of maternal care and concern. Standard due process courtroom practices also communicated bias or social exclusion, especially in a courtroom split by race and class.

Key Points for the Family Court Community:

- To minimize the effects of bias when adjudicating child maltreatment cases, family court judges should consider the application of therapeutic jurisprudence (TJ) and procedural fairness principles.

- TJ includes such practices as creating a respectful, empathetic, nonpaternalistic, and supportive environment where participants are actively engaged in the decision-making process and where cooperation rather than coercion is emphasized.

- Procedural fairness adds the perspective of lay court users and encompasses four elements: voice, neutrality, respectful treatment, and trustworthiness.

- A list of specific behaviors that exemplify TJ and procedural fairness are provided.

Keywords: Child Maltreatment Proceedings; Disproportionate Minority Representation; Family Court; Intersectionality; Procedural Fairness; Racial Bias; and Therapeutic Jurisprudence (TJ).

Virtually since its inception, juvenile court has been widely criticized on several measures, including court inefficiencies and delays, judges insufficiently attuned to the social and psychological complexity of family strife, and failing to ensure essential services and treatment (Babb, 2014; Kahn, 1953; Spinak, 2008). As one commentator succinctly noted, "As a problem-solving court, Family Court has been remarkably unsuccessful" (Spinak, 2008, p. 260). Decades of criticism have also begotten decades of reforms, both procedural and substantive. Some examples include unified courts where a single court system handles all types of family law cases and infusing a more therapeutic, problem-solving approach into proceedings (Babb, 2014).

An understudied but overarching aspect of such reforms is the salience of race, gender, and class, especially in the adjudication of child maltreatment cases. African American children are overrepresented in the child welfare system, and poor people are more likely than the affluent to be accused of child maltreatment (Boyd, 2014; Courtney, Dworsky, Piliavin, \& Zinn, 2005). Gender is also a constant presence. Women often comprise all the major players in maltreatment proceedings, from the parents, usually mothers, to the caseworkers who investigate them, the attorneys who represent both groups, the judges who preside over the cases (Miller \& Maier, 2008; Reich, 2005). The mostly female judges and lawyers are also more likely to be White, while mothers and caseworkers are often people of color (Sinden, 1999). The courtroom is also divided by class, with the legal professionals on top, followed by caseworkers, and then parents, who are predominantly poor. 
This ethnographic study of juvenile court child maltreatment proceedings describes and illuminates the ways in which racial, gender, and class disadvantages can manifest on the ground. These Manifestations occur as judges, attorneys, social service workers, and parents - joined often by gender but split by race and class - adjudicate cases.

\section{RACIAL DISPROPORTIONALITY AND DISPARITIES}

Racial disproportionalities and disparities in the child welfare system are a well-documented phenomenon (Boyd, 2014). While disproportionality rates vary geographically, certain racial and ethnic groups, including African Americans, are overrepresented compared to their percentage of the population (Children's Bureau, 2016). As an example, while African American children constitute about $14 \%$ of the population, they constitute $24 \%$ of the children in foster care (National Council of Juvenile and Family Court Judges [NCJFCJ], 2015). They also have unequal outcomes compared to other groups. African American children are more likely to endure multiple placements and longer stays in foster care and are less likely to be reunified with their parents (Harris \& Courtney, 2003). Disparities and disproportionalities are evident at all levels, exponentially increasing from the initial complaint, to placements and services, to final disposition (Boyd, 2104; Children's Bureau, 2016; Harris \& Hackett, 2008).

Decades of research and observation have suggested a myriad of reasons for these disparities. Nearly every level of society has been implicated, from structural forces such as poverty and geographic disadvantages, to family and individual-level characteristics, including substance abuse and mental illness, to institutional factors, including dysfunctional agencies with too few internal and external resources to meet service needs (Boyd, 2014; Children's Bureau, 2016; Fluke, Harden, Jenkins, \& Ruehrdanz, 2010; NCJFCJ, 2011).

One current flowing through these explanations is the impact of racial bias and discrimination. Poverty is a risk factor for child maltreatment, and African American families are more likely to be poor, not least of all due to structural and institutional racism (Fluke et al., 2010). While individual and family factors, such as substance abuse and mental illness, among others, can affect people of all incomes and ethnicities, being poor and Black whilst living in structurally disadvantaged communities, can exacerbate hardship and limit access to needed supports and services (Dettlaff \& Rycraft, 2008).

Racial bias and discrimination can also infiltrate the child welfare system (Boyd, 2014; Cross, 2008; Harris \& Hackett, 2008). Child maltreatment cases involve subjective judgments about human behavior; there is thus ample opportunity for implicit bias, and the stereotypes it triggers, to seep in and substitute for more nuanced judgments, especially when mental shortcuts are used to process a large number of complex cases (Fraidin, 2013). The high stakes may make workers reluctant to challenge, or even acknowledge, negative stereotypes, as they strive to protect children (Cross, 2008). Adverse perceptions of a family's community may also cause workers to perceive parents as willfully refusing, rather than unable, to comply with agency directives (Miller et al., 2012). Overcoming such stereotypes requires sustained attempts to prove one's worth beyond what is expected from other groups, and hence more difficult to achieve (Miller, Cahn, \& Orellana, 2012).

Efforts to reduce disproportionality and disparity within the child welfare system have consisted of a myriad of strategies. A common first step is data gathering, including analysis of administrative data, often through task forces comprising agency and community stakeholders dedicated to addressing issues of racial disparity and disproportionality (Busch, Wall, Koch, \& Anderson, 2008; Duarte \& Summers, 2012; Miller \& Esenstad, 2015). Next steps frequently involve communitybased interventions, such as building partnerships with community agencies or institutions who serve the same population, and engaging in outreach to communities of color through communitybased agencies to build trust and create stronger networks of support for families in need (Miller \& Esenstad, 2015). 
A commonly used strategy that directly addresses both institutional and individual racism is anti-racist training for both child welfare professionals and community members (Johnson, Antle, \& Barbee, 2009; Miller \& Esenstad, 2015). Anti-racist training recognizes that both institutional policies and practices, and individuals' implicit bias affect how cases are handled, and that racial bias can operate subrosa, subconsciously shaping people's attitudes and beliefs and influencing their perceptions of people of color (Greenwald \& Banaji, 1995). Training and workshops are educative, focusing on culturally competent practices and how race demonstrating racism affects families and communities, and transformative, helping individuals recognize and overcome their own implicit bias.

Of particular relevance to this study are similar efforts in the courts, specifically aimed at judges to sensitize them to the effects of implicit bias and racial disproportionality and disparities. As one example, several courts have implemented the use of "Benchcards" for judges adjudicating child maltreatment cases to monitor their own biases, within the context of best practices in judicial decision making. The Benchcards include a series of reflection questions that are designed to surface biases and encourage judges to integrate parents, children, and family members into the hearing process in a respectful way (NCJFCJ, 2011). A study of their use found that they improve courtroom practices, including parental engagement and quality of discussions, and that reunification rates increased after the Benchcards' introduction (Russell \& Summers, 2013).

The study contributes to this effort by providing a finely grained picture of how bias may surface in the courtroom during ordinary courtroom interactions. It also widens the lens, as described next, using the concept of intersectionality to illustrate how social categories, such as race, gender, and class interact to create discrimination or disadvantage.

\section{INTERSECTIONALITY}

The concept of intersectionality weaves together multiple strands of disadvantage to create a more complete and more complex picture of how different social groups are affected by and experience race, gender, and class. It treats these categories not as mutually exclusive, but as interacting in ways that produce a different experience than when viewed singularly - one which is exponentially more marginalizing (Crenshaw, 1989). The concept is particularly relevant to child maltreatment proceedings where many of the respondents are not only women and mothers, but also women of color and women experiencing poverty.

Gender operates on several levels in dependency courts. The first level is the subject matter that characterizes dependency courts: domestic relations, (in this study, the maltreatment of children) which functions as a flashpoint for gendered norms and expectations around mothering. Women are more likely to care for children than men, and as Reich (2005) found in her study of a child protection court, the expectation that they do so willingly and well is firmly entrenched as a social norm (Reich, 2005). Thus, women charged with child maltreatment are marked by a perceived failure of this gendered norm (Breger, 2012). On the other hand, most of the time, respondents will be talking to other women. Unlike many other courts, dependency courts are a space controlled primarily by women. ${ }^{1}$ Respondents are likely to appear before a female judge and be represented by a female attorney (Miller \& Maier, 2008). Thus, gender is in many ways an unpredictable card.

Child maltreatment cases are also intertwined with class, which adds more complexity and layers of disadvantage. As with gender and race, class stereotyping and bias (both explicit and implicit) create barriers. There is a strong streak of victim blaming within the discourse around poverty. The poor are often portrayed as personally defective and lacking in personal responsibility, a view that undergirds much of welfare policy (Handler \& Hasenfeld, 2007). Structural causes are often eschewed in favor of explanations that focus on individual weaknesses. Such views are especially pernicious in child maltreatment cases where poverty abounds, but where courts (and child welfare agencies) are not equipped to ameliorate it or even address it (Kemp, Marcenko, 
Hoagwood, \& Vesneski, 2009). Instead, group-based stereotypes about the poor, which are virtually wholly negative, may become the default position.

This is especially the case for poor Black women, where negative and enduring stereotypes abound. One such stereotype is that of the welfare queen, a mythologized - and always Blackwoman who is poor because of laziness and aversion to work, conniving in her welfare dependency, promiscuous in her sexual habits, and by extension, deficient in her mothering ability (Lens, 2013). It thus encapsulates the intersection of race, gender, and class in one simplistic, perceptual shorthand that suggests poor Black women may be unable to care properly for their children.

\section{METHOD}

This study draws on data from a dependency court located in an urban area in the Northeast. The data is the result of a focused ethnography, a type of sociological ethnography that examines specific and well-defined interactions, acts, or social situations in the field, rather than an entire system or culture (Knoblauch, 2005). Focused ethnography is characterized by relatively short-term field visits and intensive data collection to observe specific structured events or activities. It is particularly well suited to the observation of courtroom interactions - a form of structured social interaction bounded in space and time, with a well-defined beginning, end, and cast of characters.

94 child welfare and abuse proceedings were observed over a 1-year period between 2012 and 2013 , with 46 observations conducted by the author and 48 conducted by a research assistant. The observations were cross-sectional, involving snapshots of cases, and were not followed from the beginning to the end of a case. The unit of observation was the judge and was designed to capture each judge's judicial behaviors and demeanors over multiple cases. During the time period of the observations, nine judges were assigned to hear child maltreatment cases. Eight of the nine judges were observed multiple times over multiple observation days and, with one exception, were observed both by my research assistant and myself at different times. The use of two researchers observing the same site allowed observations to be cross-checked, thus increasing the trustworthiness of the data (Erlandson, Harris, Skipper, \& Allen, 1993). To capture the full range of a judge's behaviors and demeanors, each judge was observed until saturation which occurs "when the data show redundancy and reveal no new information" (Padgett, 2017, p. 134). The research was also approved by an Institutional Review Board.

Judges were assigned cases randomly and cases were not distinguished by level of severity. Thus, all of the judges' caseloads were similar to one another. Initially, all types of proceedings involving child abuse and neglect were observed, including initial intakes; emergency removal hearings; factfinding hearings, where charges of abuse or neglect are adjudicated; and dispositional or permanency planning hearings, where decisions are made as to where the child will live. Initial observations revealed a distinction between formal court processes, such as the taking of testimony, and less formal ones, where court actors discussed the family's progress and service needs after a charge of maltreatment was adjudicated or admitted. This study focused on the latter as they were less scripted than more formal, trial-like procedures and hence, more revealing of the ways in which judges and court actors interacted when discussing rehabilitative efforts or urging compliance with court orders.

During the hearings, a detailed log was maintained recording both what was said (as much as could be captured) and other observations. Other observations include physical descriptions of the parties and the environment of the room; obvious states of emotions (e.g., anger, crying, laughter); the parties' demeanor, tone, and style (e.g., authoritarian, conciliatory, antagonistic); and quality of personal interactions (e.g., friendly, hostile, apathetic). Routine, standardized data for each hearing observation was also recorded; this included the parties present, the issue that prompted the hearing, and the length of the hearing. Field jottings and observations were transferred into full field notes immediately after actual observations. In-process memos were used to "identify and develop 
analytic themes" (Emerson, Fretz, \& Shaw, 1995). Data sessions were conducted between the author and a research assistant, who, as noted above, had also conducted observations. The purpose of these meetings was to compare our analysis and interpretation of the data and to reach consensus on the defining themes and their properties and dimensions.

There are diverse ways to interpret and represent ethnographic data; within one study various tales can be told drawing from different perspectives (Miller, Creswell, \& Olander, 1998; Van Maanen, 1988). The first set of findings focused on judicial strategies regarding parents' participation and compliance with court orders (Lens, 2017). Thematic analysis was used, which has been defined as a "method for identifying, analyzing and reporting patterns (themes) within data" (Braun \& Clark, 2006; Guest, MacQueen, \& Namey, 2012). This analysis revealed two very divergent approaches with some judges discouraging participation and using harsh methods to secure compliance, and other judges using a softer, more therapeutic and collaborative approach.

After reporting the findings of this analysis (Lens, 2015, 2017) the data was then reanalyzed from a critical ethnographic perspective, which allowed consideration of the larger social and structural context in which dependency courts operate. As described by Cannella and Lincoln (2009), critical perspectives recognize the power dynamics embedded in societal and institutional structures and the salience of race, gender, and class. It acknowledges the existence of oppression and injustice and their corrosive effects on social and institutional interactions. To illuminate these dynamics, it seeks to examine from the perspective of disenfranchised groups how the gears of power and its corollary - disempowerment - operate in everyday settings. It is especially attuned to the "usages of language and the circulation of discourses that are used to shape all social life," including "language games that maintain power relations, and appear to prevent transformative action" (Cannella \& Lincoln, 2009).

Critical ethnography, as a qualitative method, draws from the theoretical framework of constructionism, or a belief that reality is constructed through social interaction of which there may be multiple perspectives (Cannella \& Lincoln, 2009; Padgett, 2017). As applied to ethnographic field research, it rejects the notion that there is one objective and fixed truth that can be recorded by a researcher but instead various subjective truths. Referred to as the "reflexive turn" in qualitative research, this framework "understand[s] reality as complex, allowing multiple interpretations, shifting in meaning depending upon the researcher's theoretical concerns and orienting questions" (Emerson, 2001). It thus looks at a phenomenon from different perspectives and refracted through different lenses, in this case, the intersectionality of race, gender, and class. It is interpretive by nature, as is qualitative research in general.

Taking the first set of findings as a starting point, I asked in greater detail and depth how race, gender, and class may have affected courtroom interactions, a component not fully explored previously. Capturing intersectionality, and the cross-cutting effects of bias, either implicit or explicit, is a difficult endeavor. Interactions that occur in individual cases, for example a judge admonishing a parent for her behavior, can have many explanations for its source including prior interactions between the parties and the particular facts of the case. Judges have their own particular styles and operate relatively autonomously within their courtrooms. Finally, bias does not announce itself in the courtroom, rather it exists in the often-subtle interplay between the parties and even the visual tableau that constitutes a courtroom. This reanalysis of the data was animated by a single question designed to account for such variations and subtleties: How do certain patterns of interactions across multiple cases and judges look when viewed through the lens of gender, race, and class?

As is the case with all qualitative research, the findings are limited to the site studied. Although not generalizable (a concept typically associated with quantitative research), the value of qualitative findings instead lies in their depth and detail of a phenomenon, and which may be applicable to other similar settings (Padgett, 2017). As noted above, poor women of color are overrepresented in dependency courts. Hence, findings that offer insights into how race, gender, and class may shape courtroom interactions may be applicable to the many courts with a similar demographic makeup as the study site. 


\section{FINDINGS}

The dependency court observed for this study was a space populated primarily by women. Nearly two-thirds of the respondent parents observed were women. Women constituted even higher percentages of the legal and social work participants. Of the eight judges observed, seven were women. Eighty-three percent of the attorneys representing the child welfare agency were female, while women constituted $70 \%$ of the attorneys representing the parent or child. Finally, $82 \%$ of the child welfare workers were women.

When viewed through the lens of color, the court looked very different, with race a dividing line. All but one of the parents observed were African American or Latino. Most, if not all, were also of low socioeconomic status. Similarly, of the 98 caseworkers observed, only 3 were not people of color. In contrast, most of the legal professionals were White, as is much of the judiciary. ${ }^{2}$ Of the eight judges, six were White. Seventy-one percent of the agency attorneys observed were White, as were $74 \%$ of the attorneys representing the parent or child.

\section{SOUNDS OF SILENCE}

As is true of the adversarial system in general, child maltreatment proceedings are structured around legal professionals speaking on behalf of lay people. It is a protective mechanism, designed to prevent any damaging and harmful evidence from being disclosed in open court. Navigating the law and a courtroom also requires expertise and knowledge. Leaving parents to fend for themselves would only further exacerbate their powerlessness (Sinden, 1999). While not required under the Constitution, many jurisdictions thus provide counsel to indigent parents in child maltreatment cases (Edwards, 2013).

The demographic divide between the legal professionals and respondents resulted in visually unsettling images. A lone parent, usually a woman and virtually always of color, typically sat among a bevy of mostly White attorneys and judges. They often sat huddled and silent in their chair as the attorneys bustled around them. They were separated by both color and clothing. Unlike all the other court actors, they had no place to hang their coats. They rarely shed them, thus signaling their outsider status, a temporary visitor in contrast to the professional actors who were garbed in office clothes or court uniforms.

Customary and routine rituals also took on a different hue when viewed through the prism of color. The swearing-in ritual, at the start of most proceedings, was tinged with separateness. It was a ritual not of inclusion, but differentiation as it was required only of the parent and often the caseworker, who was also likely to be a woman of color. It distinguished them from the other mostly White court actors, whose words appeared to flow freely, without being subject to the test of truth.

Parents' voices were rarely heard, as others spoke for and about them. They mostly remained silent as intimate details of their domestic lives were discussed, from how their children were faring to the parent's progress in drug treatment or anger management classes. While judges occasionally engaged parents directly, most of the dialogue flowed through the attorneys, who, like in a game of telephone tag, were the conduit for any communication between the judge and parent. Silencing of parents sometimes took on a physical aspect, as when attorneys gestured with their arms outstretched in front of their client, signaling them to stop speaking. Other times, they interrupted, speaking over clients who persisted in talking.

A courtroom custom of referring to the parent as "the mother" when spoken about and the generic "Ma'am" when spoken to produced another form of erasure. While attorneys were often respectfully referred to by their formal surnames, parents were not, thus diminishing their individuality. The pace of cases, with parents exiting and entering the courtroom in 15- to 20-minute intervals, added to this erosion, as one case quickly blurred into another.

In sum, parents had little opportunity to shape their story on their own terms and in their own words. To be sure, their silencing can be attributed to the rules and norms of the adversarial system, 
including the obligation of attorneys to zealously represent their clients. However, when viewed through the lens of color and class, courtroom rituals, rules, and norms can take on a different tinge; they can emphasize demographic differences and marginalize the most powerless. As described next, constructing the stories of the mostly poor and Black parents was largely the work of the legal and social work professionals.

\section{CONSTRUCTING NEGATIVES}

More often than not the narratives constructed by the legal and social work professionals were of blame, helplessness, and dependency, with parents' as objects to be molded and rehabilitated. Since most of the respondents were women, gender was always a subtext, as they were accused of violating the sanctity of motherhood and dominant beliefs about what constituted good mothering (Breger, 2012; Reich, 2005). There was little time or room for drawing out the complexity of the parents' lives, which were reduced to the sum of a negative act, rather than the complex whole. And while most parents remained silent as narratives were constructed, some resisted, albeit unsuccessfully, to shift them.

A particularly dramatic example involved a mother who had allowed her child to visit with the father, despite an Order of Protection preventing such contacts. The hearing began with a request that the child be removed from the home and returned to foster care. The visibly upset mother tried to challenge the decision but was thwarted by the judge, who repeatedly silenced her, verbally and then physically when she ejected her from her own hearing:

Upon hearing that she was to lose custody of her child for allowing the visit, the parent first tried to communicate through her attorney, who told the judge "it's hard for [the mother] to accept that after three years" of rebuilding the relationship with her child she will be separated from her." The mother again tried to speak, but was cut off by the judge, who glared at her, telling her "Ma'am, that's enough!" As she continued to cry and leaned over to speak with her attorney, the judge told her "This will be the last time that I warn you. If you continue you'll be asked to leave...Look at me when I'm speaking to you!"

The mother spoke anyway, asking that the foster mother not be allowed at the child's school because it would interfere with the child's progress. The judge responded by stating "Ma'am, I am asking you to stop speaking." After a brief discussion among the attorneys regarding the mother's allowing the visit with the father, the judge issued an order that "At this time, there will be NO community visits." In response, the mother began crying more audibly.

The judge addressed the "concerns of the court [regarding the mother's] poor judgment and poor insight..." and stated that the child would be remanded. The mother again began to speak, to object to the decision. In a loud, harsh, and reprimanding tone the judge said to her "You made your decision" when she allowed the child to see the father and noted that "This court finds it very [disturbing] that the mother seems less concerned for the comfort and wellbeing of her child than for herself."

The judge then indicated to the court officers that the mother was to leave the court, gestured for her to get up, and reiterated that, "you need to leave." Once the mother was out of the courtroom, she began wailing and screaming in the lobby. Shrieks and cries were audible from the courtroom after the door had closed, with the mother repeatedly yelling, "It's not fair!"

After she left, the judge, shaking her head and scowling said to the remaining court actors, including the attorneys and caseworker, "I find the mother's behavior in court today rather appalling." She began reviewing the orders, including one that stated that "The mother is not to be within one hundred yards of that school."

The attorney for the mother addressed the judge, "I would just like to point out that it seems it is alright for another person to be on the phone (the caseworker was speaking on her cell phone) but it is not alright for my client to speak." The judge did not respond.

This case vividly illustrates the power of a judge to silence respondents and to build narratives unencumbered by opposing storylines, even as parents are represented by attorneys. By describing the respondent as a "mother [who] seems less concerned for the comfort and wellbeing of her child 
than for herself," the judge invoked a stereotypical belief about motherhood: "good" mothers cared only for others and not themselves. The mother's emotional response- to cry at the loss of her childwas treated as a transgression rather than a sincere expression of motherly pain. When the mother attempted to assert her parental prerogative to make decisions about her child, it was swiftly rejected by the judge, who told her "to stop speaking." Absent was any counternarrative that might explain the mother's decision to allow the visit with the father, thus illustrating the judge's power to create a powerful and negative narrative, based on an albeit serious incident, but without exploring all of its intricacies. Failing to protect children from dangerous others-including the men in their life - was viewed as a singular and catastrophic failure of motherhood, despite the complicated dynamics surrounding domestic violence.

While some narratives were written large, others were more commonly built by smaller moments, which, when strung together, produced a reductive and often one-dimensional portrait of parents. An illustrative example involved a dispute over whether a doctor had canceled an appointment or the mother missed it. With no fact finding, it was quickly attributed to the mother's negligence, with the judge telling the mother, "you are going to call [and reschedule the appointment] as soon as you step out of the courtroom." Spoken as an order, in a tone that conveyed distrust and irritation, it transformed a relatively minor dispute into a commentary on the mother's character, portraying her as errant and irresponsible.

Negative narratives were also difficult to dislodge, despite potential turning points as a parent's progress was being monitored. In this same case, a report of a clean drug test was followed by a request for continued testing, which the judge quickly ordered while admonishing the mother, "If you have a no-show, I will assume it's positive. If it comes back diluted, I will assume it's positive." Thus, instead of emphasizing the positive (a clean drug test) the judge chose to speculate about future failures, while also implying that the mother could not be trusted to follow through.

Narratives are also shaped by what is left out. While poverty was a constant undertone, it was rarely brought to the surface. Neither was the larger structural context within which parents lived their lives or the confounding variables of race and discrimination. While a court's purview is the micro, not the macro, the failure to acknowledge structural obstacles reinforced narratives of personal irresponsibility. As an example, a parent accused of educational neglect was chastised by the judge for not trying hard enough to locate a tutor for her child, despite the caseworker's statement that tutors were difficult to find. In short, a lack of resources was framed as a lack of initiative.

Drug use was evident in a portion of the cases, and its handling implicated issues of race and class. Parents were subject to random drug tests, with marijuana use treated as a serious infraction that signaled poor parenting. Thus, much like the role marijuana plays in the incarceration of Black men, or Black women, it is a route to the possible loss of their children through the civil justice system. Juxtaposed against the increasing acceptance of marijuana among more affluent White citizens and the trend toward legalization, this double standard suggests the adverse influence of race and class when judging poor parents of color, particularly in the legal system.

Like a quickly drawn painting, narratives were constructed with swift and bold strokes. The brief courtroom interactions - most lasted less than 20 minutes - left little room for exploring the complexities of parents' lives. This lack of time is endemic to institutions like the dependency court, which must process a high number of cases quickly and efficiently. Such brief interactions invite a more one-dimensional and stereotypical picture of people. For respondents, who are marked by allegations of child maltreatment and stigmatized by race, gender, and class, these stereotypes are mostly wholly negative. As described next, negative narratives invited harsher and more punitive treatment of parents and also spilled over and affected interactions among the other nonlegal professionals in the room - the caseworkers.

\section{SHAMING RITUALS}

Shame is the specter hanging over virtually all child maltreatment proceedings. As Reich observed in her in-depth study of a child protective agency, mothers charged with child 
maltreatment are subject to "a special form of contempt reserved for mothers, particularly those who are unmarried" (Reich, 2005). As she further explains, the measure of a "good mother" is a gendered one, "with mothers presumed to be children's primary natural caretakers" (p. 60) and with motherhood requiring "self-restraint" and sacrifice" (p. 25). Motherhood also requires resources, and those resources, including safe and stable housing, adequate daycare, reliable transportation, and enough income to provide for basic needs are out of reach for most poor women. Racial barriers and discrimination may also make it more difficult for families of color to amass the requisite resources. ${ }^{3}$ However, structural obstacles are largely ignored in the context of dependency court, nor is it within the capacity or purview of the court to provide those resources (Nelson, 1997; Reich, 2005). Thus, at the precise moment when mothers must prove their worth and capabilities, they must do so without the resources the more affluent, and society in general, consider essential for taking care of children.

Rather, individual behavioral change is the court's animating force, with judges choosing from a limited menu of options, such as drug treatment or anger management and parenting classes. When these and other court-ordered interventions or commands failed to fully rehabilitate mothers, the mothers were often chastised for their lack of compliance. Such moments became grist for shaming rituals within the courtroom.

Shame was communicated in a variety of ways, some more overt than others, as when judges described a parent's behavior in emotionally laden and degrading ways or used stern and harsh language and body language. As an example, after being told that a recent visitation had been cut short when the mother and stepmother had an altercation, the judge loudly and forcibly said, "If there is any such behavior, the agency is to suspend visits immediately." While scowling, pointing, and wagging a pen, she then told the mother, "I will not have adults behaving inappropriately in front of the children." Another example is the interaction described above wherein the judge repeatedly and harshly berated the parent throughout the proceeding, ending with the statement, "I find the mother's behavior in court today rather appalling."

A more in-depth analysis of the educational neglect case also described above, wherein the parent was blamed for not obtaining a tutor for her child, further illustrates the use of overt shaming. Throughout this proceeding, the judge repeatedly belittled her efforts to find a tutor, portraying all of her actions as inadequate. Thus, when the mother explained that the daughter was on a waiting list for tutoring and that she sent a letter to the school through her child to request tutoring, her attempts were framed as failures. The judge told her that "a waiting list is not helpful here" and that "[i]t isn't the child's job to hand in a letter." After asking the mother if she had a computer, the judge chastised her for not using it to help her child, telling her, "if you are using a computer at work, you should be using it at home to look for tutoring." The mother's response - that she did "her best"- was rejected by the judge, who told her, "It's not about doing your best." By condemning both the mother and her actions, the judge employed a particularly corrosive form of shaming; instead of attempting to integrate the mother back into the community through respect and forgiveness, she treated her as effectively unredeemable. ${ }^{4}$

Other shaming incidents were subtler and comprised smaller moments that signaled a lack of respect and social exclusion and hence unworthiness. One such example was when judges failed to use respondents" names, instead using the generic "Ma'am" or "mother" while calling higher-status legal professionals by their surnames. Shaming was also implicit in the ways in which judges dictated compliance, rather than soliciting it and often after a decision was made without the mother's participation. An illustrative example involved a teenage daughter in residential treatment with a tumultuous relationship with her mother. As the mother sat silently, the judge, attorney, and social worker discussed her child's emotional state and problems, the mother's clean drug tests, and the type of therapy appropriate for the family. After announcing her decision to maintain the goal of returning the child to her mother, the judge directly addressed the mother for the first time. The judge told the mother, "I want you to keep working on your relationship," asking her whether she was engaged in individual counseling, (to which she answered with a simple yes) and telling her, "you need to be supportive." The mother's peripheral role, first during the discussion and then as a 
passive recipient of the judge's orders, positioned her not as a respected and active participant, but as an object to be worked on, a status that suggests powerlessness and unworthiness. This example also illustrates how shaming episodes need not be showy or loud; such moments can also be found in mundane and often quiet rituals and routines.

\section{CASEWORKERS}

Shaming and silencing rituals were not confined to parents, and they permeated other aspects of courtroom interactions. As noted above, often the only other woman of color in the courtroom along with the mother was the child welfare worker. Amidst the legal professionals, such workers also occupied a lower professional status. As the legal adversary of the parent(s), they also played a different role. They not only served as witnesses but were often the fulcrum of the proceeding. Judges relied on them to provide crucial information about the family and its progress and to facilitate court orders. Through their reports and visits, caseworkers know more about parents than most anyone else in the courtroom.

Like parents, caseworkers were more likely to be drowned out by the legal professionals in the room, with attorneys acting as the conduit for information gathered by caseworkers. Caseworkers sometimes provided crucial information in their own words; but at other times, questions within their purview - for example, about family life, the relationship between a mother and a foster parent, or the conditions of a home-were communicated by an attorney, rather than through a direct colloquy with the caseworker who had observed and collected the information. As with parents, this dynamic reflected the rules of the adversarial system, as caseworkers were represented by an attorney in the courtroom. It also served as an expeditious shortcut for judges, who had little time to continually consult with all those present. The two central figures of the proceeding, the caseworker and the mother, were adversaries to one another but they shared a common bond of race; they both receded into the background as the mostly White and female legal professionals argued their cases.

Caseworkers were also at times the targets of a judge's ire. Child welfare agencies are often criticized for inefficiency and ineptness (see, e.g., Bernstein, 2002), with caseworkers a readily available and visible target. A worker's efficacy is being measured alongside a parent's progress. As with parents, they are thus vulnerable to being shamed for perceived mistakes or negligence.

Shaming came in a variety of forms, from how judges addressed caseworkers to their criticism of the worker's efforts in open court. Judges used common linguistic conventions for communicating disrespect and disregard, such as speaking loudly and harshly over caseworkers, slowly articulating their words as though caseworkers could not understand them, and interrupting them, even while they were responding to the judge's own questions. These styles of communication had a shaming effect because they impugned workers' integrity and competence.

Judges also directly condemned the quality of workers' efforts. An illustrative example involved a caseworker's report that directly contradicted evidence submitted in court, showing that a parent was not reporting to drug testing. The caseworker, who was sitting in the back of the courtroom, was ordered to stand by the judge. Using the appellation "Ma'am," rather than the caseworker's name (a sign of disrespect), the judge loudly and harshly confronted her with the contradictions, without soliciting the reasons for them. As the caseworker responded, admitting to her "oversight', the judge cut her off; turning her attention to the caseworker's attorney, the judge demanded that the caseworker's supervisor monitor the case and come to court because "the court cannot rely on this caseworker's reports."

At other times, judges registered their dissatisfaction with a few quick words. When a dispute arose over the condition of a family's home, the judge chastised the worker for not taking pictures, saying "I recommend that you [take some pictures next time] so we don't waste the court's time with conflicting reports." In the busy setting of dependency court, where time was limited, "wasting the court's time" was a common and effective refrain for quickly expressing dissatisfaction. 
Caseworkers also bore the brunt of the perceived failings of the child welfare agency or individual workers. In one such example, the judge chastised a caseworker covering for another worker (who was in the hospital) because of a missing court report, telling her, "the excuses are no longer sufficient in this court. Because of this I am having to take time away from other [cases]," and then continuing to criticize her for not being adequately prepared. In a different instance, echoing that example, a worker's explanation for an insufficient report - that the report was dated and that changes had since taken place in the agency-was interrupted by the judge who, speaking slowly, loudly, and deliberately to the caseworker while furrowing her brow in a frown, told her "so next time you'll hand in a report that's accurate." In another instance, the judge was upset that the agency had not held a crucial conference about what services the family needed, having instead only "explored" possible options. This judge told the caseworker in an impatient and irritated voice, “"explore' means you are doing nothing... I don't make my rules based on your conferences. If I waited for [the agency] to do conferences the cases will take years. I'll give you a week and a half for the conference."

The common thread in such exchanges was an assumption of incompetence on the part of both the worker and the agency and a willingness to address agency missteps or failures by publicly denigrating workers and their efforts. While attorneys were sometimes treated harshly by the judges, judges' ire was more likely to fall on caseworkers. They were rarely praised for their work and, similar to parents, were castigated in shaming episodes triggered by their perceived failings. On the one hand, this similar treatment suggests comity between the two designated adversaries, parents and the agency/caseworker, with the legal professionals playing a different role. Both the agency's performance and the parents' acts and behaviors occupy center stage in proceedings and are open to judgments. But when viewed through the lens of race and class, the picture looked less benign because of the racial makeup of the courtroom where parents and caseworkers were largely women of color and their interrogators mostly White and female legal professionals. ${ }^{5}$

\section{DISCUSSION}

One enduring image of justice is embodied in the figure of "Lady Justice," pictured with a blindfold over her eyes. It is an allegorical image that suggests justice is blind and hence will be dispensed fairly and without bias. Similarly, the ideal judge, as described by codes of judicial conduct, is neutral and impersonal, swayed not by values or ideology but by the facts and the law. The adversarial process is likewise designed to create a neutral playing field, as litigants, armed with their respective attorneys, shape their stories and arguments before the court. These goals are often more aspirational than real (Sunstein, Schkade, Ellman, \& Sawicki, 2006). Neither judges nor courts are value free and both are more likely than not to reflect the dominant values and ideology of a society. Nor are courts a neutral palate; they are shaped by the social identities of the people who interact within them.

Detecting when marginalization is occurring is a difficult task. Discrimination and bias are rarely made explicit but are contained in a myriad of gestures, words, and attitudes that shame, silence, or slight people. As the findings describe, even commonplace courtroom rituals and procedures like the swearing in of parents and caseworkers, or the silencing of their voices by their attorneys, take on a different, albeit unintended, tinge because of their social identity as subordinated groups.

Intersectionality worked in ways that exponentially marginalized poor mothers of color in the courtroom, primarily through the construction of narratives which emphasized individual weakness over structural obstacles and personal irresponsibility over expressions of maternal care and concern. To be sure, such narratives are arguably endemic to child maltreatment cases, both because of the paramount value placed on the protection of children, and the nature of adjudication, which is case-specific and focused on the individual acts of parents. However, the presence of such narratives, within courtrooms populated primarily by poor mothers of color, produced a distinctly 
gendered, classed, and racialized view of the neglectful mother, an "other" who does not fit privileged societal notions of good mothering (Reich, 2005).

Caseworkers, of marginally higher status in the courtroom, were treated in similar ways; while respondents were constructed as incompetent mothers, caseworkers were constructed as incompetent workers. Both were subject to shaming within the courtroom as they were chastised for their perceived faults and depicted as hopelessly flawed. Such shaming rituals, when continually performed against a subordinated group, can reinforce race-based stereotypes.

Adversarial procedures designed to protect can exclude rather than amplify voices. The lawyerclient relationship is a hierarchical one, with lawyers holding the reins of what story to tell and how to tell it (Felstiner \& Sarat, 1991-1992). Class and race can complicate even the most wellintentioned lawyer's choices. Even lawyers for the poor can subordinate and marginalize clients, substituting lawyer-driven narratives for client-driven ones (Alfeiri, 1991; Felstiner \& Sarat, 1991-1992; White, 1990). The silencing of poor mothers of color by their white middle-class lawyers can hence be, at once, a protective gesture and an exclusionary one.

Judges, despite efforts to remain impartial and unbiased, can also act in ways that marginalize parents. Implicit bias and the stereotypes that it triggers exist in all strata of society, and courtrooms have their own version of it. As studies have demonstrated in the related context of juvenile justice and criminal courts, in fast-paced courtrooms where the stakes are high and there is much uncertainty, judges will rely on a perceptual shorthand or scripts to make decisions. These are based not only on the law but also on stereotypes and attributions linked to the defendant's race and other characteristics (Albonetti, 1991; Eisenstein, Flemming, \& Nardulli, 1988; Gibson, 1983). Judges will also draw on their collective experience and understanding of typical cases, leaving less room for understanding individual attributes and more room for applying group stereotypes and collective biases (Johnson, 2006).

The particular milieu of dependency court provides fertile ground for this dynamic. Judges must predict not only whether there is a risk of immediate harm to the child but also whether a parent is sufficiently rehabilitated to care for the child. They must make this determination based on a few short and sporadic interactions with the parents (who are mostly silent in court) and information supplied by others, including caseworkers' reports and other sources of information. The homogenous makeup of respondents - most of whom are poor women of color-invites the shortcut of substituting stereotypes in place of more individualized assessments. As Breger (2012) explained, dependency court is fertile ground for stereotyping, as "mothers in Family Court are so ubiquitous that they essentially become invisible" (p. 556). She further argued that this "often leads players in the Family Court system to rely upon gendered norms and roles in making critical and enduring decisions" (p. 556). The disadvantages of both race and class add another dimension to this marginalization.

\section{POLICY AND PRACTICE IMPLICATIONS}

As noted earlier, several approaches have been employed to address bias, including anti-racist training and reflection tools such as Benchcards, designed to surface bias in real time as judges make decisions. While such training and tools are helpful, the judiciary has some additional—and unique - tools at its disposal. They include the judiciary's institutional values, which emphasize due process and equality under the law, and the singular power of the judge, who sets the tone and tenor of courtroom interactions.

Institutional legal norms and procedures are erected around the principles of due process. It manifests in myriad ways in a courtroom, including the turn-taking that gives each party an opportunity to be heard and the emphasis on a neutral and unbiased judge. Thus, strategies for reducing bias already have a scaffold from which to build. One mechanism for enhancing these institutional values is to emphasize procedural fairness (also known as procedural due process), which stresses what litigants view as fair and unbiased judging. 


\section{Table 1}

\section{Positive Courtroom Behaviors}

\begin{tabular}{|c|c|}
\hline Respect & Neutrality and Trust \\
\hline $\begin{array}{l}\text { - Introduced him or herself at the beginning of the proceeding } \\
\text { - Personally welcomed the parent into the courtroom } \\
\text { - Made eye contact when speaking and listening to the parent } \\
\text { - Used body language (nodding, tilting forward, eye contact) that } \\
\text { - Referred to the parent by surname (for example, Ms. Brown rather } \\
\text { than the "mother") } \\
\text { - Used plain language that avoided legal jargon or acronyms } \\
\text { - When setting the next court date, asked the parent what date/times } \\
\text { would be convenient for him or her }\end{array}$ & $\begin{array}{l}\text { - Clearly explained the purpose of the proceeding } \\
\text { and the court process } \\
\text { - Was prepared for the proceeding } \\
\text { - Listened carefully and patiently } \\
\text { - Treated all of the participants the same } \\
\text { - Clearly explained the reasons for his or her } \\
\text { decisions } \\
\text { - Helped parents to understand decisions and } \\
\text { what they must do as a result }\end{array}$ \\
\hline Voice & Support \\
\hline $\begin{array}{l}\text { - Gave parents the opportunity to speak and voice their perspectives } \\
\text { (i.e. allowed them to complete their thoughts and their answers to } \\
\text { questions) } \\
\text { - Spoke directly to the parent in a manner that encouraged dialogue } \\
\text { - Asked open-ended questions that invited more than a simple "yes" } \\
\text { or "no" response } \\
\text { - Asked parent if he or she had any questions }\end{array}$ & $\begin{array}{l}\text { Made supportive comments, such as praising, } \\
\text { complimenting, or reassuring the parent } \\
\text { - Conveyed a sense of caring, compassion, or } \\
\text { empathy } \\
\text { - Demonstrated interest in the needs, problems, } \\
\text { and concerns of parents } \\
\text { - Acknowledged parent's emotional responses to } \\
\text { the case or court events (i.e. crying) }\end{array}$ \\
\hline
\end{tabular}

Source: The author's observations and various judicial performance evaluation programs and other sources that have operationalized the attributes of therapeutic jurisprudence and procedural fairness including the Court Room Observation Program of the Utah Judicial Performance Evaluation Commission (Leben, 2011); The Center for Court Innovation, Procedural Justice: Practical Tips for Courts (Lagratta, n.d.); National Judicial Institute, Problem-Solving in Canada's Courtrooms: A Guide to Therapeutic Justice; and The Solution-Focused Judging Bench Book (King, 2009).

Procedural fairness encompasses four elements: voice, neutrality, respectful treatment, and trustworthiness (Tyler, 2006). Voice means the opportunity to tell one's story, to actively contribute to, and shape the narrative of events. Neutrality requires an unbiased decision-maker who is transparent about how decisions are made. Respect means dignified and courteous treatment. Trustworthiness requires expressions of benevolence, sincerity, and concern. While these elements parallel in part legal definitions of due process, they also add a different perspective - that of lay users; they thus invite judges to see the courtroom through the respondents' eyes.

Such a view illuminates how even standard due process courtroom practices and rituals can communicate bias or social exclusion, especially in a courtroom split by race and class. This includes both routinized and seemingly innocuous rituals, such as the swearing-in, and overall patterns of communication, including the dominance of attorneys in the courtroom, who often speak over, and instead of, their clients. Judges should become more aware of these dynamics, balancing them out with more welcoming, inclusive, and participatory gestures to both respondents and other court actors, including caseworkers. As noted by the author in her earlier findings (Lens, 2017), some judges are more apt to engage respondents in "information dialogues" than other judges, thus demonstrating how even within the confines of the adversarial process such exchanges are possible.

Judges, as choreographers of the proceeding, can also minimize or exacerbate the effects of bias in ways that more secondary and less powerful actors cannot. Unlike other bureaucracies where power is more diffused and hierarchical, judges sit at the center. A judge's behavior can ripple throughout the courtroom, creating either a supportive and inclusive environment or an intimidating and corrosive one. One way to encourage the former is for judges to utilize the principles of therapeutic jurisprudence $(\mathrm{TJ})$.

TJ views legal rules and procedures and legal actors as therapeutic or anti-therapeutic agents that affect participants' psychological well-being (Winick, 2002). The tools of TJ draw from the 
psychological and behavioral sciences for motivating positive behaviors. An approach often used in problem-solving courts, including some dependency courts, TJ includes such practices as creating a respectful, empathetic, nonpaternalistic, and supportive environment where participants are actively engaged in the decision-making process and where cooperation rather than coercion is emphasized (Winick, 2002-2003). As this author (Lens, 2015) found, TJ can be adopted in even the most underresourced and overburdened of dependency courts.

Using both the principles of procedural fairness and TJ together is especially potent. While several of its precepts overlap (e.g., an emphasis on voice and respect), they also complement one another. Dependency courts, with their emphasis on rehabilitation rather than punishment, are fertile ground for applying TJ principles (Babb, 2014). Procedural fairness can ensure that a therapeutic approach does not devolve into a form of paternalism that dilutes individual rights.

The combined components of TJ and procedural fairness - respect, voice, neutrality and trustworthiness, and support - are also easily translatable into a set of behaviors, both verbal and nonverbal (see Table 1). As some examples show, seemingly routine courtroom rituals, such as initial introductions and how respondents are referred to, can convey respect by the judge personally welcoming the parent and using his or her surname. To engage parents, judges can ask open-ended questions that require more than a yes or no answer. Judges can convey a sense of caring by acknowledging parents' emotional responses and expressing support and empathy.

To be sure, TJ and procedural fairness are not a substitute for anti-racist training, which addresses bias and discrimination at its source. Instead, they act as protective barriers against bias by inviting and standardizing judicial behaviors that ensure all parents are treated well and fairly. TJ and procedural fairness also have the added advantage of improving courtroom practices overall, thus helping dependency courts better fulfill their mission of rehabilitating families.

\section{NOTES}

1. While the composition of the judiciary is changing, and there are more women judges than ever before, courts are still primarily the province of men. Overall, throughout the state judiciary, about one third of judges are women (National Association of Women Judges, 2016).

2. Nationwide, $14 \%$ of the judges in state courts are people of color (American Bar Association, 2013).

3. People of color earn about half of what whites do, and white families have six times the net worth of people of color (Hill, 2004).

4. For a discussion of the application of stigmatizing shaming versus re-integrative shaming, see Ray, Dollars, and Thames (2011).

5. One study of caseworkers found that being older, white, and male was associated with higher degrees of comfort in family courts (Faller, Grabarek, \& Vandervrot, 2009), thus suggesting that one's race, and not only one's role, affects how courtroom interactions are experienced.

\section{REFERENCES}

Albonetti, C. (1991). An integration of theories to explain judicial discretion. Social Problems, 38, 247-266.

Alfieri, A. V. (1991). Reconstructive poverty law practice: Learning lessons of client narrative. Yale Law Journal, 100, 2107-2147.

American Bar Association. (2013). A current glance at women in the law. Chicago, IL. Retrieved from https://apps. americanbar.org/abanet/jd/display/national.cfm \#4

Babb, B. A. (2014). Family courts are here to stay, so let's improve them. Family Court Review, 52, $642-647$.

Bernstein, N. (2002). The lost children of Wilder. New York, NY: Vintage.

Boyd, R. (2014). African American disproportionality and disparity in child welfare: Toward a comprehensive conceptual framework. Children and Youth Services Review, 37, 15-27.

Braun, V., \& Clarke, V. (2006). Using thematic analysis in psychology. Qualitative Research in Psychology, 3, $77-101$.

Breger, M. L. (2012). The invisibility of motherhood in family court proceedings. New York University Review of Law \& Social Change, 36, 555-591.

Busch, M., Wall, J. R., Koch, S., \& Anderson, C. (2008). Addressing disproportionate representation of children of color: A collaborative community approach. Child Welfare, 87, 255-278. 
Cannella, G., \& Lincoln, Y. (2009). Deploying qualitative methods for critical social purposes. In N. Denzin \& M. Giardina (Eds.), Qualitative inquiry and social justice (pp. 53-72). Walnut Creek, CA: LCoastPress.com.

Children's Bureau. (2016, November). Racial disproportionality and disparity in child welfare. Child Welfare. Retrieved from https://www.childwelfare.gov/pubPDFs/racial_disproportionality.pdf

Courtney, M. E., Dworsky, A., Piliavin, I., \& Zinn, A. (2005). Involvement of TANF applicant families with child welfare services. Social Service Review, 79, 119-157.

Crenshaw, K. (1989). Demarginalizing the intersection of race and sex: A black feminist critique of antidiscrimination doctrine, feminist theory and antiracist politics. University of Chicago Legal Forum, 1989, 139-167.

Cross, T. L. (2008). Disproportionality in child welfare. Child Welfare, 87(2), 11-22.

Dettlaff, A. J., \& Rycraft, J. R. (2008). Deconstructing disproportionality: Views from multiple community stakeholders. Child Welfare, 87(2), 37-58.

Duarte, C. S., \& Summers, A. (2013). A three-pronged approach to addressing racial disproportionality and disparities in child welfare: The Santa Clara County example of leadership, collaboration, and data-driven decisions. Child Adolescent Social Work Journal, 30, 1-19.

Edwards, L. (2013). Representation of families and children in abuse and neglect cases: The importance of early appointment. Juvenile Family Court Journal, 63(2), 21-37.

Eisenstein, J., Flemming, R., \& Nardulli, P. (1988). The contours of justice: Communities and their courts. Boston, MA: Little, Brown.

Emerson, R. (2001). Contemporary field research: Perspectives and formulations. Prospect Heights, IL: Waveland Press.

Emerson, R. M., Fretz, R. I., \& Shaw, L. L. (1995). Writing ethnographic fieldnotes. Chicago, IL: University of Chicago Press.

Erlandson, D. A., Harris, E. L., Skipper, B. L., \& Allen, S. D. (1993). Doing naturalistic inquiry: A guide to methods. Thousand Oaks, CA: Sage.

Faller, K., Grabarek, M., \& Vandervort, F. (2009). Child welfare workers go to court: The impact of race, gender, and education on the comfort with legal issues. Children and Youth Services Review, 31, 972-977.

Felstiner, W., \& Sarat, A. (1991-1992). Enactments of power: Negotiating reality and responsibility in lawyer-client interactions. Cornell Law Review, 77, 1447-1498.

Fluke, J., Harden, B., Jenkins, M., \& Ruehrdanz, A. (2010). Research synthesis on child welfare disproportionality and disparities. American Humane Society. Retrieved from https://www.acf.hhs.gov/sites/default/files/cb/es2011_session_104.pdf

Fraidin, M. (2013). Decision-making in dependency court: Heuristics, cognitive biases, and accountability. Cleveland State Law Review, 60, 913-974.

Gibson, J. (1983). From simplicity to complexity: The development of theory in the study of judicial behavior. Political Behavior, 5, 7-50.

Greenwald, A., \& Banaji, M. (1995). Implicit social cognition: Attitudes, self-esteem, and stereotypes. Psychological Review, $102,4-27$.

Guest, G., MacQueen, K. M., \& Namey, E. E. (2012). Applied thematic analysis. Thousand Oaks, CA: Sage.

Handler, J., \& Hasenfeld, Y. (2007). Blame welfare: Ignore poverty and inequality. Cambridge, MA: Cambridge University Press.

Harris, M. S., \& Courtney, M. E. (2003). The interaction of race, ethnicity, and family structure with respect to the timing of family reunification. Children and Youth Services Review, 25, 409-429.

Harris, M. S., \& Hackett, W. (2008). Decision points in child welfare: An action research model to address disproportionality. Children and Youth Services Review, 30, 199-215.

Hill, R. (2004). Institutional racism in child welfare. Synthesis of research on disproportionality in child welfare: An update. Washington, DC: Institute for Policy Studies, Racial Inequality.

Johnson, B. (2006). The multilevel context of criminal sentencing: Integrating judge and county level influences. Criminology, 44, 259-298.

Johnson, L. M., Antle, B. F., \& Barbee, A. P. (2009). Addressing disproportionality and disparity in child welfare: Evaluation of an anti-racism training for community service providers. Children and Youth Services Review, 31, 688-696.

Kahn, A. (1953). A court for children: A study of the New York City Children's Court. New York, NY: Columbia University Press.

Kemp, S. P., Marcenko, M. O., Hoagwood, K., \& Vesneski, W. (2009). Engaging parents in child welfare services: Bridging family needs and child welfare mandates. Child Welfare, 88(1), 101-126.

King, M. (2009). Solution-focused judging bench book. Melbourne, Australia: Australasian Institute of Judicial Administration Inc.

Knoblauch, H. (2005). Focused ethnography. Forum: Qualitative Research, 6(article 44).

Lagratta, E. (n.d.). Procedural justice: Practical tips for courts. New York, NY: Center for Court Innovation.

Leben, S. (2011). Considering procedural-fairness concepts in the courts of Utah. Midway, UT: Educational Conference of the Utah State Courts.

Lens, V. (2013). Welfare queen. In Blackwell encyclopedia of race, ethnicity and nationalism. Wiley-Blackwell.

Lens, V. (2015). Against the grain: Therapeutic judging in a traditional family court. Law \& Social Inquiry, 41, 701-718.

Lens, V. (2017). Engaging parents in family court: Lessons from an observational study of child protection cases. Journal of Social Work, 17, 129-146. 
Miller, K. M., Cahn, K., \& Orellana, E. R. (2012). Dynamics that contribute to racial disproportionality and disparity: Perspectives from child welfare professionals, community partners, and families. Children and Youth Services Review, 34, 2201-2201.

Miller, D., Creswell, J., \& Olander, L. (1998). Writing and retelling multiple ethnographic tales of a soup kitchen for the homeless. Qualitative Inquiry, 4(1), 469-491.

Miller, O., \& Esenstad, A. (2015). Strategies to reduce racially disparate outcomes in child welfare: A national scan. Washington, DC: Center for the Study of Social Policy. Retrieved from https:/www.cssp.org/publications/child-welfare/ alliance/Strategies-to-Reduce-Racially-Disparate-Outcomes-in-Child-Welfare-March-2015.pdf

Miller, S., \& Maier, S. (2008). Moving beyond numbers: What female judges say about different judicial voices. Journal of Women, Politics \& Policy, 29, 527-559.

National Association of Women Judges. (2016). U.S. state court women judges. NAWJ. Retrieved from https://www.nawj. org/statistics/2016-us-state-court-women-judges

National Council of Juvenile and Family Court Judge. (2011). Right from the start: The CCC preliminary protective hearing benchcard study report. Reno, NV: Author.

National Council of Juvenile and Family Court Judges. (2015). Disproportionality rates for children of color in foster care: Fiscal year 2013. Reno, NV: Author.

Nelson, K. (1997). Family preservation: What is it? Children and Youth Services Review, 19, 101-118.

Padgett, D. (2017). Qualitative methods in social work research. Thousand Oaks, CA: Sage.

Ray, B., Dollar, C. B., \& Thames, K. M. (2011). Observations of reintegrative shaming in a Mental Health Court. International Journal of Law and Psychiatry, 34, 49-55.

Reich, J. A. (2005). Fixing families: Parents, power, and the child welfare system. New York, NY: Routledge.

Russell, J., \& Summers, A. (2013). An overview of the courts catalyzing change preliminary protective hearing benchcard study. Juvenile and Family Court Journal, 64(2), 1-16.

Sinden, A. (1999). "Why won't mom cooperate?":A critique of informality in child welfare proceedings. Yale Journal of Law and Feminism, 11, 339-396.

Spinak, J. M. (2008). Romancing the court. Family Court Review, 46, 258-274.

Sunstein, C., Schkade, D., Ellman, L., \& Sawicki, A. (2006). Are judges political: An empirical analysis of the federal judiciary. Washington, DC: The Brookings Institution.

Tyler, T. (2006). Why people obey the law. Princeton, NJ : Princeton University Press.

Van Maanen, J. (1988). Tales of the field: On writing ethnography. Chicago, IL: University of Chicago Press.

White, L. E. (1990). Subordination, rhetorical survival skills, and Sunday shoes: Notes on the hearing of Mrs. G. Buffalo Law Review, 38, 1-58.

Winick, B. J. (2002-2003). Therapeutic jurisprudence and problem solving courts. Fordham Urban Law Journal, 30, $1055-1090$.

Vicki Lens is a professor at the Silberman School of Social Work, Hunter College, City University of New York. Prior to earning her Ph.D. in social welfare, she worked as a legal aid lawyer and as an assistant attorney general in New York. Her primary research interest is in socio-legal studies, where she uses ethnographic and other methods to study legal settings, among them the family court. She is the author of Poor Justice: How the Poor Fare in the Courts (Oxford University Press). She has presented her research and assisted in the training of family court judges and other court personnel at the Judicial Institute and the New York City Family Court. 